УДК 902/904 (574)

https://doi.org/10.24852/2587-6112.2021.6.132.147

\title{
КУЛЬТ ВОЛКА В КУЛЬТУРЕ НАСЕЛЕНИЯ КАЗАХСТАНСКОГО ПРИУРАЛЬЯ VI-IV ВВ. ДО Н.Э.
}

\section{(C) 2021 г. Я.А. Лукпанова}

В статье рассмотрены особенности погребального обряда и инвентаря, связанных с изображением волка, проанализирован образ волка в искусстве, в культе, верованиях. В зверином стиле Казахстанского Приуралья широко распространено изображение волка и отдельных частей его тела в мужских и женских погребениях на предметах вооружения, узды, зеркалах, проколках, навершиях, жертвенниках. Зубы, клыки, лапы, челюсть волка встречаются в составе украшений, в ритуальных комплексах погребений, они использовались в обрядах и ритуалах, являлись амулетами. Волк и его образ рассматриваются не только как символ, но и как один из важных компонентов погребального обряда, отражающего статус человека. В культуре народов образ волка наделялся сверхъестестенными характеристиками, он являлся мифологическим образом, его образ сакрализирован, воинские союзы, образованные в раннекочевническом обществе после обряда инициации создавались по принципу волчьей стаи, а воины назывались воинами-псами. Волк рассматривается как символ, как один из важных компонентов погребального обряда. Части тела волка в погребениях отражали тотемистические взгляды ранних кочевников Приуралья

Ключевые слова: археология, Казахстанское Приуралье, курган, погребение, волк, семантика, культ, ритуал, обряд, хаома.

\section{THE CULT OF THE WOLF IN THE CULTURE OF THE POPULATION OF THE KAZAKHSTAN URAL OF THE $6^{\text {TH }}-4^{\text {TH }}$ CENTURIES BC}

\section{Ya. A. Lukpanova}

The paper discusses the features of the burial rite and inventory associated with the wolf's image, and analyzes the wolf's image in art, cult and beliefs. In the animal style of the Kazakhstan Urals, the image of a wolf and individual parts of its body are frequently found in male and female burials on weapons, bridles, mirrors, piercers, finials, and altars. Wolf's teeth, fangs, paws and jaw are found as part of jewelry, in ritual burial complexes, they were used in rites and rituals, and as amulets. The wolf and its image are considered not only a symbol, but also one of the important components of the funeral rite, reflecting the status of a person. In the culture of the peoples, the wolf's image was endowed with supernatural characteristics, it was a mythological image, and it was sacralized. Military unions formed in the early nomadic society after the initiation rite were created on the principle of a wolf pack, and warriors were referred to as dog warriors. The wolf is considered a symbol and one of the important components of the funeral rite. The body parts of a wolf in the burials reflected the totemistic views of the early nomads of the Ural region.

Keywords: archaeology, Kazakhstan's Urals, mound, burial, wolf, semantics, cult, ritual, rite, haoma.

\section{Введение}

В культурном пространстве ранних кочевников Приуралья VI-IV вв. до н.э. изображение волка является одним из распространенных образов в погребальном обряде, в искусстве, при этом он имел многочисленные проявления в социальном, культовом, семантическом, культурологическом значении. Образ волка, один из самых ярких проявлений звериного стиля в искусстве ранних кочевников Степного Приуралья. Волк один из самых мифологизированных, неоднозначных фигур. Он чаще всего ассоциировался с потусторонним миром. Е.Ф. Королькова отмечает, что среди локальных особенностей сложившегося звериного стиля Приуралья мотив волка является преобладающим в изображениях, причем фигура волка представлена в различных положениях и на различных предметах, это неудивительно, так как в данном случае имело место и отражение местной фауны в верованиях и традициях.

Источниковой базой являются предметы, обнаруженные в погребениях из памятников Казахстанского Приуралья: Бесоба, Сынтас, (раскопки М.К. Кадырбаева), Володарка (раскопки Г.А. Кушаева), Булдурты (раскопки А.А. Бисембаева), Тонкерис (раскопки Р.С. Мергалиева), Кырык-оба (раскопки С.Ю. Гуцалова, Ж. Курманкулова, Ж.Е. Смаилова), Таксай-1, Таксай-3 (раскопки автора). 
Характеристика и анализ материала.

Могильник Бесоба расположен возле поселка Сарыжар (бывш. пос. Хлебодаровский, Мартукский р-н, Актюбинская обл.), раскопки М. К. Кадырбаева 1973, 1974, 1976 гг. Здесь были обнаружены захоронения представителей родоплеменной знати VI-IV вв. до н. э., наряду с погребениями воинов были открыты и женские погребения в персональных курганах и в коллективных захоронениях (Кадырбаев, 1974).

Курган 3 (диаметр - 38,0 м, высота - 36,0 м) имел шатровую надмогильную конструкцию возвышающуюся над центральным погребением, принадлежащим женщине (Кадырбаев, 1974, c. 3). Головой она была ориентирована на запад с легким отклонением на юг. Инвентарь представлен украшениями, декором одежды в виде нашивных бляшек, бронзовым зеркалом, ножом, терочником и красками, крупным сосудом с носиком-сливом. На уровне бедренной кости был найден большой каменный жертвенник на трех зооморфных ножках (рис. 1: 1). Ножки выполнены в виде скульптурной головы волка с оскаленной пастью и округлыми ушами, снизу жертвенник орнаментирован рельефной трехлепестковой фигурой, рядом с жертвенником был обнаружен миниатюрный сосуд, реальгар, точильный камень. В южной половине могильной ямы находился прямоугольный очаг глубиной 5,0 см или кострище. Рядом с очагом, вплотную к нему, были положены части туши лошади (Кадырбаев, 1974, c. 5).

Курган № 9 (высота - 3,0 м) со сложной бревенчатой конструкцией, представлял собой восьмигранную гробницу. В кургане обнаружено коллективное захоронение, два из которых зафиксированы на прямоугольной погребальной площадке с восточной и западной стороны, на уровне древнего горизонта в виде земляного стола, принадлежали они мужчинам. Третье, женское погребение располагалось обособлено, за пределами площадки. В центральной части площадки зафиксированы сосуд, кости лошади и нож.

Западное захоронение покоилось на деревянных носилках. На шее мужчины обнаружена гривна, у изголовья предмет в виде жезла, плакированный золотым листом. Рядом с мужчиной находился колчан со стрелами, акинак, копье длиной 1,7 м. Восточное захоронение было ограблено в древности, но здесь были найдены бронзовые бляхи с фигурой двугорбого верблюда и с изображением свернувшегося в кольцо хищника - волка (рис. 1: 2)(Кадырбаев, 1984, с. 89].

В кургане 12 могильника Бесоба (диаметр - 15,0 м, высота - 0,5 м) было выявлено пять захоронений на уровне древнего горизонта, все погребения разрушены. Инвентарь представлен двумя глиняными сосудами, ножкой каменного жертвенника с изображением в виде оскаленной морды волка, бронзовое зеркало, фрагмент бронзового котла.

Могильник Сынтас был расположен в 10,0 км юго-западнее пос. Сарыжар (бывш. пос. Хлебодаровский, Мартукский р-н, Актюбинская обл.)

Курган 1 (диаметр - 26,0 м, высота - 1,4 м) с шатровой погребальной конструкцией. В кургане обнаружено четыре погребения. Одно погребение было совершено в центральной яме глубиной 0,5 м, три погребения на уровне древнего горизонта вокруг центральной могилы. Погребение 1 принадлежало мужчине, головой ориентированного на юг. В могиле были обнаружены у изголовья три бронзовые пряжки от узды, железный нож, у пояса акинак с брусковидным навершием и бабочковидным перекрестием. Справа от погребенного обнаружено конское снаряжение, состоящее из удил, железных двудырчатых псалиев, пронизей, фигурных пряжек и пуговицевидных пронизей. На двух пронизях изображены волки (рис. 1: 3). Здесь же лежал колчанный набор из 49 бронзовых стрел и миниатюрная костяная ложка, рукоять которой украшена резной головой волка (рис.1: 4) с оскаленной пастью (Кадырбаев 1974, с.17).

Два воина погребены с западной и восточной части ямы, первый ориентирован головой на юг, второй на юго-запад. Инвентарь западного погребения представлен железным крючком с навершием в виде головы орлиноголового хищника, двумя сосудами, точильным камнем, двумя акинаками, железным ножом, колчанным набором, бусиной и уздой и тремя массивными пряжками с изображением сцены терзания орлиноголовым хищником травоядного животного. Инвентарь восточного погребения воина представлен колчанным набором, точильным плоским камнем, железным колчанным крючком, тремя пластинами, 

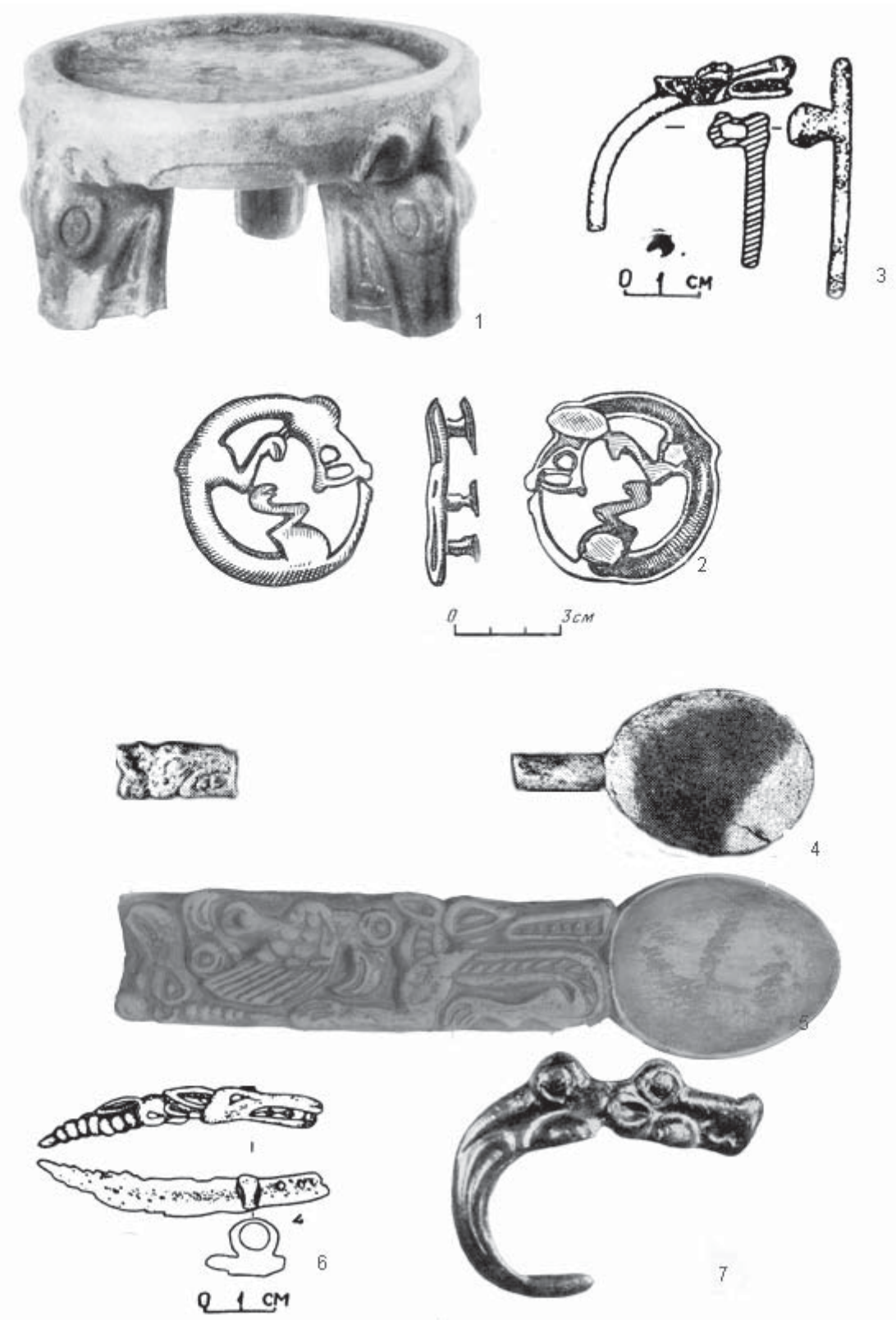

Рис. 1. Могильник Бесоба: 1 - жертвенник, курган 3 (по: Kadyrbaev, 1981, p. 33, f. 2); 2 - подпружная бляха, курган 9 (по: Кадырбаев, 1984. с. 92, рис. 5). Могильник Сынтас: 3-4 - пронизь, костяная ложка центральное погребение курган 1 (по: Кадырбаев, 1976. с. 141, рис.3; с.152, рис. 12, 2); 5-6 - костяная ложка, пронизь, восточное погребение, курган 1 (по: Кадырбаев, 1976. с. 152, рис. 12, 1; с. 145, рис. 6); 7- колчанный крюк, курган 2, центральное погребение (по: Kadyrbaev 1981, p. 35, f. 6).

Fig. 1. Besoba burial ground: 1 - altar, mound 3 (after: Kadyrbaev 1981, p. 33, f. 2); 2 - spring plate, mound 9 (after: Kadyrbaev, 1984. c. 92, fig. 5). Syntas burial ground: 3-4 - bead, bone spoon, central burial, mound 1 (after: Kadyrbaev, 1976. p. 141, fig. 3; p. 152, fig. 12, 2); 5-6 - bone spoon, bead, eastern burial, mound 1 (after: Kadyrbaev, 1976.

p. 152, fig. 12, 1; p. 145, fig. 6); 7 - quiver hook, mound 2, central burial (after: Kadyrbaev 1981, p. 35, f. 6).

под точильным камнем обнаружена костяная ложка, на широкой рукоятке которой изображена «зоологическая головоломка», состоящая из трех образов (рис. 1: 5). На верхней части ручки изображен волк с повернутой назад головой и оскаленной мордой. Шея и тело волка выделены двумя параллельными линиями, с заштрихованными линиями внутри. Под волком изображена фигура орла также с повернутой назад головой. Крыло отмечено косыми насечками, оперение передано резными чешуйками, лапа орла передана в виде кольца, прямо под ней изображена вторая голова орла, но в перевернутом виде. Ниже голова сайгака, прямые рога которой заканчиваются у лапы волка. Акинак, железный нож, две фигурные пряжки, точильный камень, две ворворки, две цилиндровые обой- 
мы, удила, у левых берцовых костей двое железных удил с псалиями, здесь же другие предметы уздечного набора среди которых массивная пронизь украшенная изображениями голов волка и джейрана (рис. 1: 6) (Кадырбаев, 1976, с. 145 , рис. 6: 4). Четвертое погребение северное, разрушено, из предметов сохранились круглодонный сосуд и камень.

Курган 2 был расположен восточнее кургана 1 (диаметер -16,0 м, высота - 1,6 м). Под насыпью кургана на уровне древнего горизонта было обнаружено два погребения. Первое разграблено, предметы разбросаны, в погребении рядом с наконечниками стрел были обнаружены два колчанных крюка из железа и бронзы. На бронзовом крюке изображение головы оскалившегося волка и орлиноголового хищника (рис.1: 7).

Курганный комплекс Володарка-1 расположен в 3,0 км севернее с. Володарка (Зеленовский p-н, Западно-Казахстанская обл. - далее ЗКО) исследован под руководством Г.А. Кушаева (Гуцалов, 2011).

Курган 3 (диаметр - 30,0 м, высота - 0,8 м) имел бревенчатую конструкцию подквадратной формы, представлявшую сруб, сооруженный на уровне древнего горизонта над ямой и перекрытый рядами массивных досок. В яме обнаружено два погребения - западное и восточное (рис. 2: 1-2).

Западное захоронение принадлежало, предположительно, мужчине, ориентированного головой на юг.

Восточное захоронение принадлежало взрослому человеку, покоившееся на левом боку. Правее тазовых костей найдена обломанная костяная ложка длиной 10,2 см, железное шило, нож и бусинки (рис. 2: 5, 7-9). В 1,0 м севернее ступней скелетов найдены крестец и ребро крупного животного, рядом с ними лежал бронзовый котел с коническим поддоном (рис. 2: 4) и двумя вертикальными ручками. Западнее котла обнаружены остатки большого лепного сосуда (рис. 2: 3). При зачистке стен ямы с южной стороны в потревоженном грунте обнаружена небольшая костяная пластина $(4 \times 1,3$ см), на которой вырезаны контуры головы волка (рис. 2: 6), вероятно обломанное навершие ложки. Оскаленная морда волка удлиненная с горбинкой, уши округлые переданы завитком, глаза хищника изображены в виде тонкой линии, пасть окаймлена рельефным валиком в ней просматриваются клыки волка.

Курганный комплекс Булдурты расположен в 2,0 км к С3 от пос. Булдырты (Сырымский р-н, ЗКО). Исследован в полевом сезоне 2003 г. под руководством Р.Е. Халелова (Памятники... 2006, с. 218-219).

$B$ кургане 2 (диаметр - 45,0 м, высота 3,0 м) была обнаружена надмогильная бревенчатая конструкция. В кургане было выявлено три погребения. Центральное погребение ограблено в древности, оно принадлежало мужчине. В яме обнаружен глиняный очаг, массивный пест с изображением головы орлиноголового хищника, блюдо из рога лося, предмет из железа.

Погребение 2 принадлежало женщине, могильная яма была перекрыта трехслойным деревянным накатом, толщина перекрытия составляла около 0,60 м, вероятно, они держались на 11 столбах, расположенных вокруг погребенного, к сожалению, сохранились только столбовые ямы и фрагменты дерева. Яма подпрямоугольной формы, углы ямы округлые, длинными сторонами ориентирована по направлению С3-ЮВ. Скелет женщины покоился на спине, руки вытянуты, ноги сведены к стопам, головой она ориентирована на ЮЗ. На женщину были надеты украшения, гривна и серьги, между коленями в мешочке найден литой бронзовый колокольчик, орнаментированный рифлеными полосами, навершие колокольчика зооморфное. С левой стороны черепа к северу было выявлено массивное бронзовое зеркало с боковой ручкой с сохранившимися фрагментами кожаного футляра. Возле зеркала находился крупный кусок мела, реальгар. Западнее зеркала обнаружена бочонковидная, продолговатая белая бусина. Севернее скелета на уровне коленей была выявлена массивная глиняная кубкообразная курильница высотой 7,5 см, с вдавленными углублениями на дне, рядом с курильницей находились два галечных камня, на уровне средней части берцовой кости. Особый интерес вызывают предметы, обнаруженные с правой стороны погребенной на массивном камне подквадратной формы с прямоугольным углублением в центральной части. Здесь обнаружены предметы из трубчатой кости мелкого рогатого животного (?), крючок из кости, предмет из железа в деревянных ножнах обтянутых кожей, предмет из 

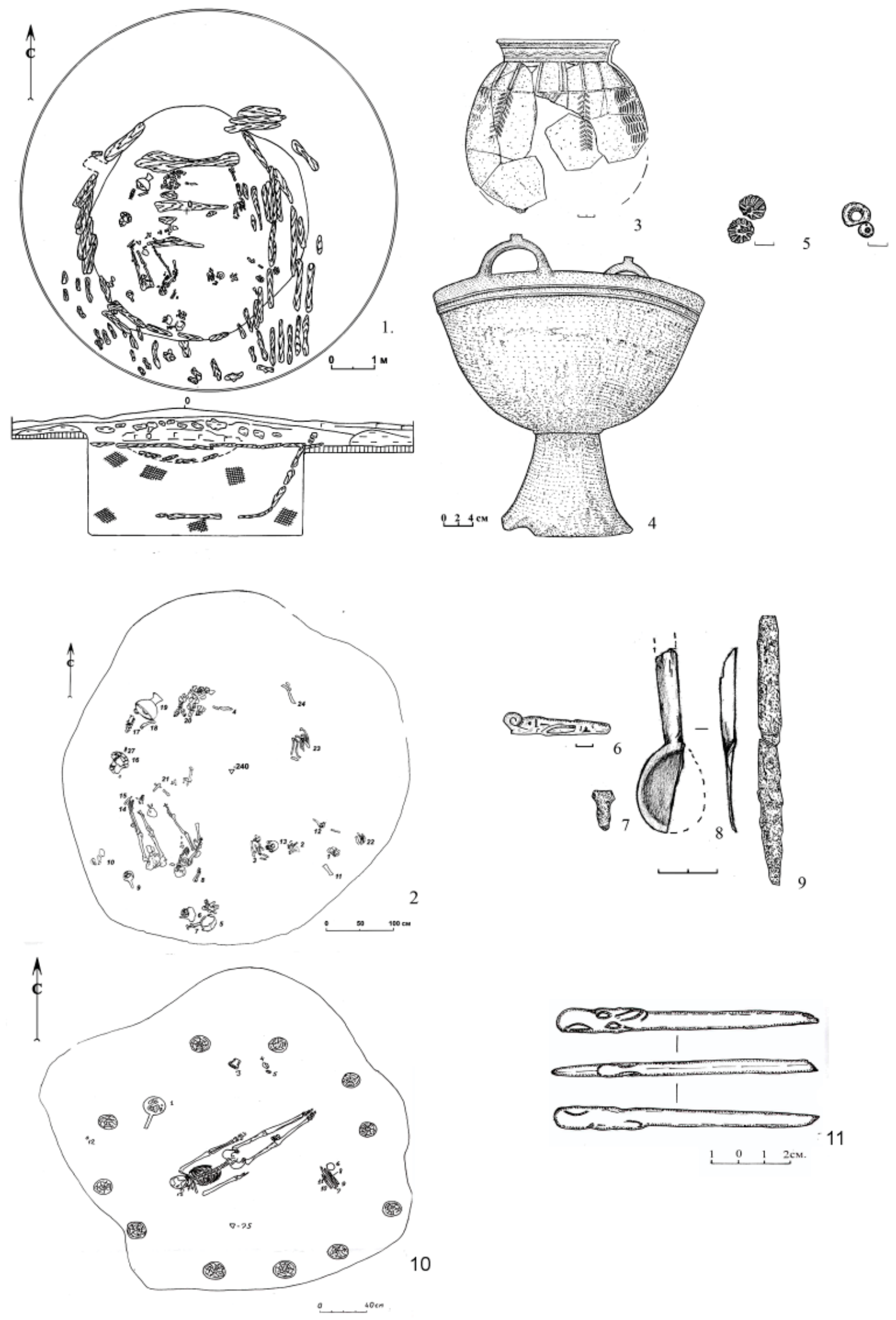

Рис. 2. Могильник Володарка, курган 3: 1 - план кургана; 2 - план погребения; 3 - фрагменты большого сосуда; 4 - котел; 5 - шило; 6 - пластина с изображением волка; 7-9 - шило, нож, бусинки (по: Гуцалов, 2011, с. 19, рис. 2 ; с.20, рис. 3 ; с. 22, рис. 4; с. 23, рис. 4) Могильник Булдурты, курган 2: 1 - проколка (по: Памятники..., 2006, c.219)

Fig. 2. Volodarka burial ground, mound 3: 1 - plan of the mound; 2 - plan of the burial; 3 - fragments of a large vessel; 4 - boiler; 5 - awl; 6 - plate with the wolf's image; 7-9 - awl, knife, beads (after to: Gutsalov, 2011, p. 19, fig. 2; p. 20, fig. 3; p. 22, fig. 4; p. 23, fig. 4). Buldurty burial ground, mound 2: 1 - bead (after: Monuments..., 2006, p. 219) 
бронзы в виде длинного литого прута и костяная проколка, с навершием в виде вытянутой морды, оскаленного волка (рис. 2: 11).

Погребение 3 принадлежало женщине, головой ориентированной на СЗ. Курганный комплекс Кырык-оба-2 расположен в 5,0 км от п. Даниляколь (Бурлинский р-н, ЗКО), на левом берегу р. Урал. Он состоял из 30 земляных насыпей, растянувшихся цепочкой с запада на восток. Могильник условно разделен на восточную часть, где насчитывается восемь курганов и западную часть с 21 археологическим объектом. Материалы могильника Кырык-оба широко освещены в научной литературе (Гуцалов, 2010, 2011; Сдыков, Гуцалов, Бисембаев, 2003; Курманкулов, Ишангали, Раймкулов, 2002). Под насыпью курганов, были выявлены сложные деревянные конструкции шатрового и срубного типов, опиравшиеся на валы, в центре которых были зафиксированы могильные ямы различной формы, наряду с такими погребениями встречались захоронения, выполненные на древнем горизонте. В погребальном обряде присутствует применение огня. Вещевой материал в погребениях могильника Кырык-Оба представлен наборами конской узды, алтариками, бронзовыми котлами, оружием, зеркалами, ритуальными предметами. Многие предметы оформлены в зверином стиле.

Значительное количество изображений волка встречается на конской узде. В кургане 2 (раскопки Курманкулова Ж.) (диаметр - 34,0х38,0 м, высота - 1,95 м), в западной периферии были выявлены три бронзовые бляхи от ремней с изображением свернувшегося в кольцо волка (Курманкулов и др. 2002, с. 88). Тело зверя выполнено пластично, спина выгнута полукольцом, передняя и задняя лапы соприкасаются на месте сгибов, занимая центр всего изображения, очень четко просматриваются когти хищника, слегка изогнутые и чуть удлиненные (рис. 3: 1). Морда хищника с небольшой горбинкой хорошо проработано треугольное ухо с валиком по краю, глаз миндалевидный выделен рельефом. Шея зверя мощная, голова крупная. Хвост хищника передан в виде одной линии с завитком на конце. В пространстве между задними лапами хищника и брюхом вставлено изображение головы грифона с загнутым к низу клювом, что подчеркивает агрессив- ность образа грифона. У грифона выделены круглые глаза и ухо в виде завитка. В целом образ хищника передан естественно, композиция замкнута, можно подчеркнуть художественные и технические достоинства, отработанные стилистические приемы, четкость изображения, завершенность.

Особый интерес вызывает бронзовая уздечная бляха из кургана 18 в виде свернувшегося в кольцо хищника с волчьей мордой (рис. 3: 2). Образ хищника передан естественно, можно подчеркнуть художественные и технические достоинства, отработанные стилистические приемы, четкость изображения, завершенность. Мотив свернувшегося в кольцо хищника достаточно широко распространен в искусстве звериного стиля скифской эпохи на всей территории ее бытования. Изображение подчинено условной композиционной схеме, задача которой - вписать тело животного в круг (Королькова, 2006, с.73). О происхождении мотива свернувшегося в кольцо хищника скифской эпохи существуют несколько точек зрения. В этом отношении заслуживает внимания мнение Ю.Б. Полидовича, предположившего об одновременном появлении и развитии мотива в разных местах (Полидович, 1994, с. 63-78, по: Засецкая, 2006, с. 77). Учитывая локальные особенности звериного стиля Южного Приуралья возможно допустить происхождение этих уздечных бляшек из данного региона.

В кургане 15 были обнаружены двудырчатые биметалические псалии, с наконечниками в виде оскаленной морды волка (рис. 3: 3). Морда волка удлиненная, узкая с хищным оскалом пасти с подчеркнутым изображением двух острых клыков и трех коренных зубов. В кургане 18 обнаружены пронизи в изображении четко прослеживается голова насторожившегося хищника, в данном случае использован элемент образа целого хищника припавшего к земле (рис. 3: 4). Еще одно стилизованное изображение волка на костяной рукоятке ножа из кургана 15 было выполнено с применением орнаментального мотива «сложного завитка» (рис. 3: 5). Одна сторона рукоятки была оформлена в виде головы волка с оскаленной пастью. Другая сторона рукояти ножа, на месте крепления к лезвию была выполнена в виде изображения кабана. 

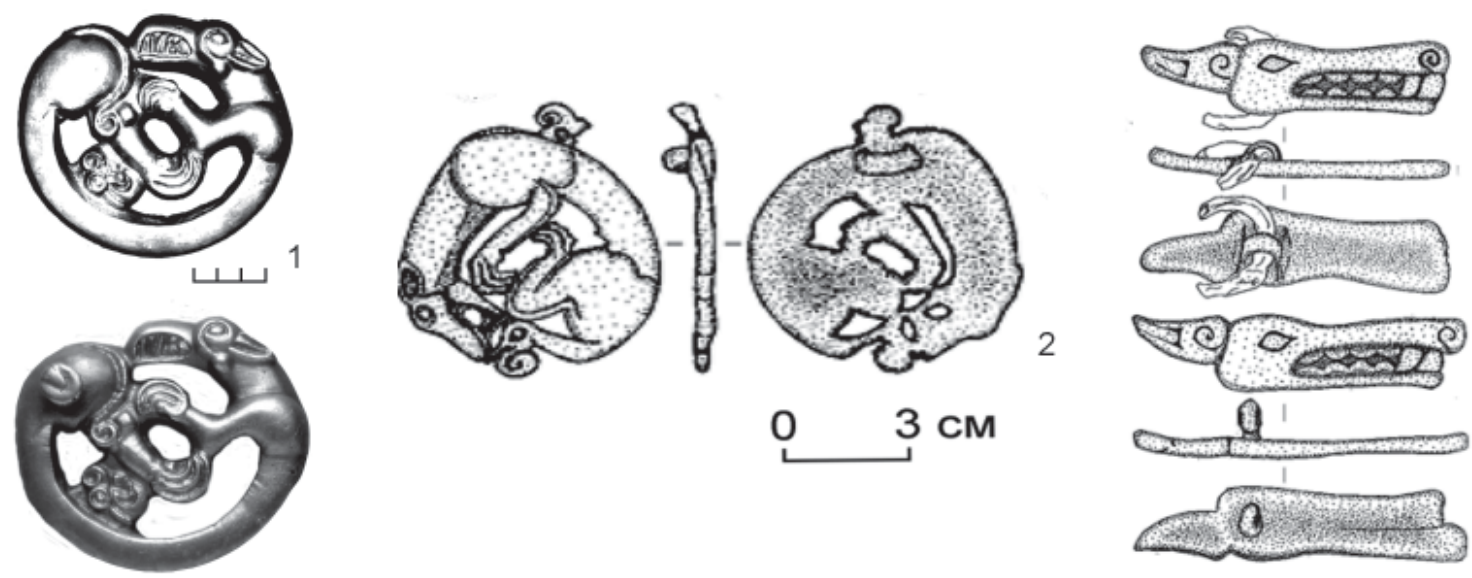

4
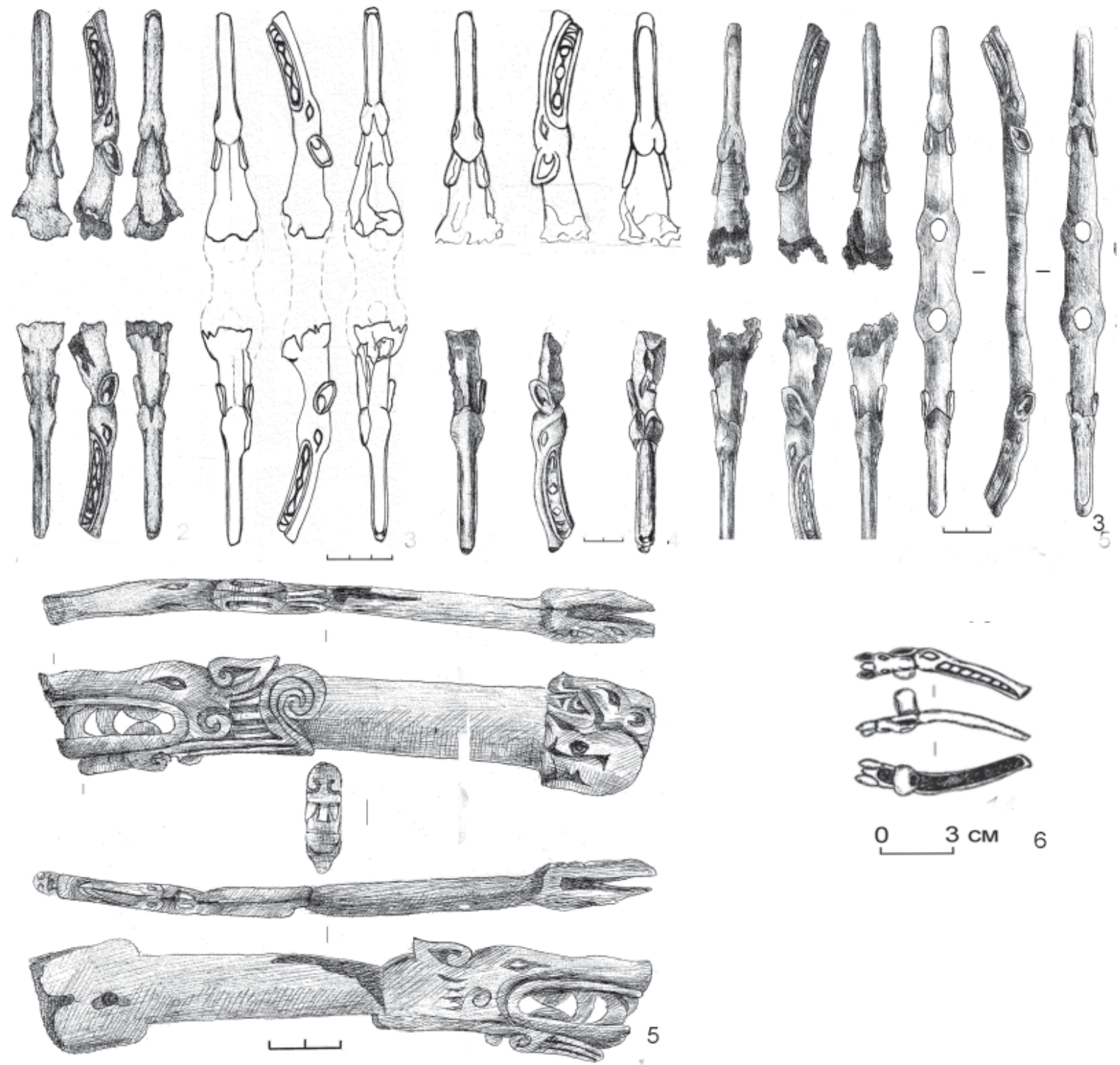

Рис. 3. Могильник Кырык-оба 2: 1 - подпружная бляха, курган 2; 2 - подпружная бляха, курган 18; 3 наконечники псалий в виде оскаленной морды волка, курган 15; 4 - пронизи, курган 18; 5 - рукоять ножа, курган 15; 6 - налобник, курган 12 (по: Гуцалов, 2007, с. 84, рис. 12; с.85, рис.13; с. 86, рис.14)

Fig. 3. Kyryk-oba burial ground 2: 1 - spring plate, mound 2; 2 - spring plate, mound 18; 3 - tips of psalia in the form of a wolf's snarling muzzle, mound 15; 4 - beads, mound 18; 5 - knife handle, mound 15; 6 - forehead piece, mound 12 (after: Gutsalov, 2007, p. 84, fig. 12; p. 85, fig. 13; p. 86, fig. 14) 
На налобниках из кургана 12 такое же изображение волчьей головы с длинной и узкой горбатой мордой с ровным рядом зубов, с выделенными ушами, но клыки у которого отсутствуют (Смирнов, 1964, рис. 80: 6). Подобная стилизация вызвана формой самого предмета и, вероятно, влиянием иного зооморфного образа - головы с длинным клювом, - который использовали для украшения узкого конца костяных и бронзовых налобников (рис. 3: б). Изображение представляет собой сложную композицию, потому что в шею волка вцепился зооморфный образ (лошадь, кошачий хищник (?)). Удлиненная пасть хищника, в частности волка, встречается в искусстве саков Приаралья. Этот прием известен и в искусстве племен древнего Прикамья в материалах ананьинской культуры, в котором мотив волчьей головы наряду с образом медведя был популярен и близок сибирско-савроматской трактовке (Смирнов, 1964, c. 233-234].

Могильник Тонкерис I расположен в 6,0 км к востоку-юго-востоку от п. Тонкерис (Теректинский р-н, ЗКО). Исследован в полевом сезоне 2003 г. под руководством Р.С. Мергалиева. Курган 3 с земляной насыпью (диаметр - 10,0 м, высота - 0,3 м). В центральной части кургана, под насыпью обнаружена яма прямоугольной формы размерами 2,0×3,5 м длинными сторонами ориентированная по оси 3-В. В яме обнаружены разрозненные погребения двух взрослых людей, кости потревожены, положение нижних конечностей сохранилось in situ. Погребенные лежали вытянуто на спине, головой ориентированы на восток. Вещевой материал представлен каменным столиком и пестом, наконечниками стрел и бронзовым зеркалом со скульптурным изображением двух голов волка (рис. 4: 1) с оскаленной мордой в зеркальном отображении на нижней части ручки зеркала (Лукпанова, 2007, с. 68-69).

Могильник Таксай-1 расположен в 8,0 км южнее пос. Долинное (Теректинский p-н, ЗКО). Исследован в полевом сезоне 2012 г. под руководством автора. Курган 6 (диаметр - 41,0 м, высота - 1,0 м) имел бревенчатую шатровую конструкцию. Погребальный обряд выполнен с применением огня. На уровне древнего горизонта с двух сторон центральной ямы были обнаружены сопроводитель- ные погребения двух женщин. Основное погребение было зафиксировано в центральной яме, подквадратной формы в виде сруба, перекрытого двойным бревенчатым накатом (Сдыков, Лукпанова 2013; Лукпанова, 2016, c. 156). Основное погребение принадлежало женщине-жрице, судя по наличию значительного количества ритуальных предметов, обнаруженных в яме. Вещи были представлены украшениями из золота, нашивными бляшками с изображением протомы орлиноголовых хищников, архаров, стеклянными сосудами, подвесками-амулетами, бронзовым котлом, жаровней, пятью комплектами узды, ножами, обкладками деревянного сосуда. В ореховом коробе были сложены ритуальные предметы представленные кистью волка, ножом, деревянным гребнем, сосудиком, зубами и клыками волка. Южная стена ямы была оформлена в виде заходящего солнца, под полудиском были сложены бляшки, подвески и зубы волка в золотых обкладках (рис. 4: 2) . В погребении таксайской женщины не встречаются изображения волка, но здесь присутствуют лапы, клыки и зубы волка среди ритуальных предметов (рис. 4: 4), на рукава платья женщины были нашиты амулеты-подвески из зубов и клыков волка в золотых обкладках (рис. 4: 3) (Алтынбеков, 2013; Лукпанова, 2017). Несмотря на то, что изображения волка на предметах отсутствуют, но в украшениях, среди ритуальных предметов присутствуют части тела хищника, прослеживается поклонение образу волка.

Курганный комплекс Таксай-3 расположен в 5,0 км юго-восточнее пос. Долинное (Теректинский р-н, ЗКО), раскопки были проведены под руководством автора в 2017 г. (Лукпанова, 2018).

Курган 2 (диаметр - 40,0 м, высота - 1,0 м). Под насыпью кургана был обнаружен глиняный вал, прерывающийся с южной стороны. Внутренняя поверхность вала была покрыта корой дерева, а от самого вала к яме радиально были уложены бревна, ветки, верх которых покрыт мелкими ветками и корой. Центральную яму вытянутую длинными сторонами с запада на восток перекрывал бревенчатый накат. К югу от нее отходил дромос, который соединялся со второй ямой округлой формы.

Погребение принадлежало трем воинам, покоившимся на органической подстилке, 

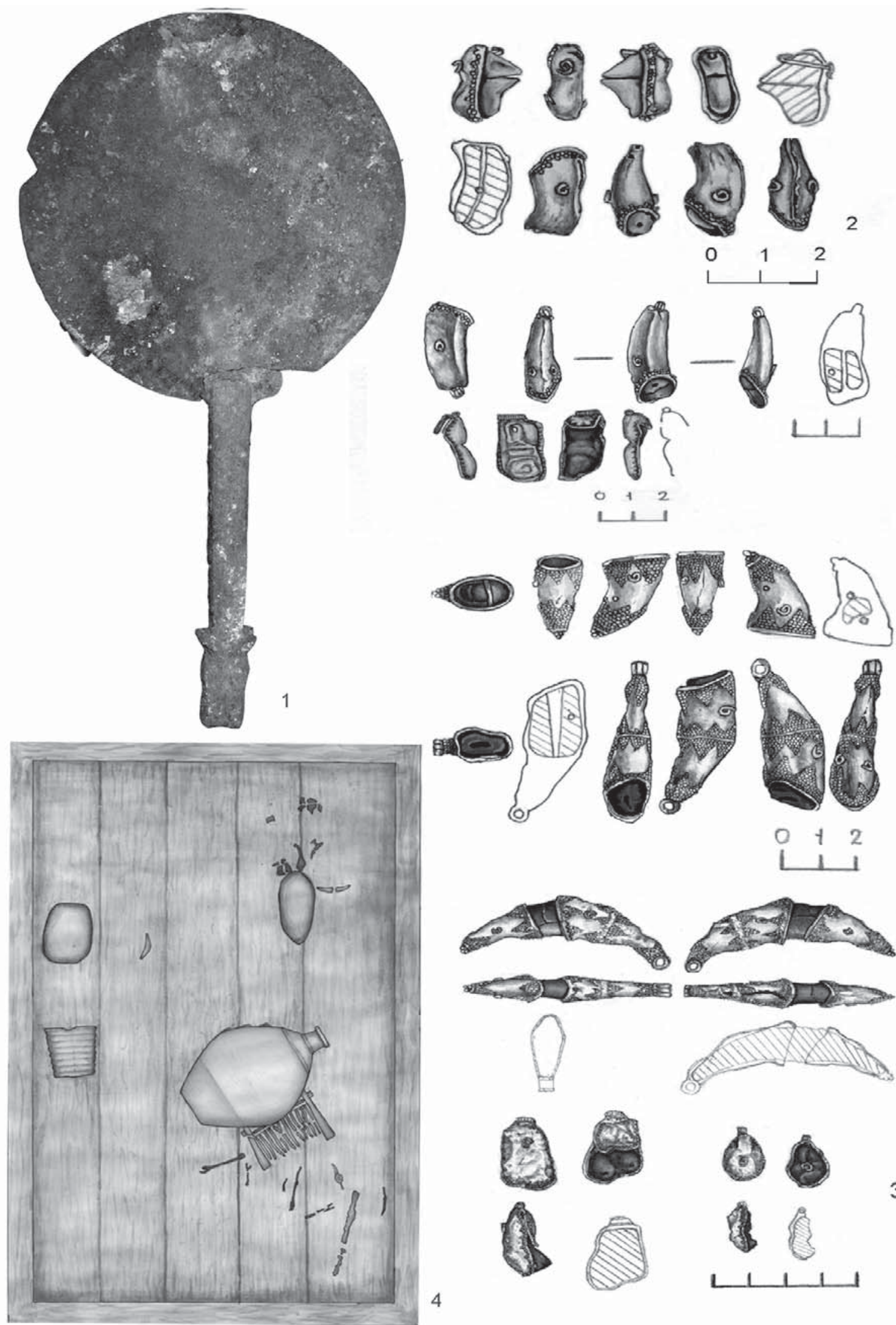

4
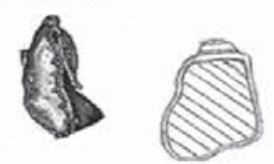

3

Рис.4. Могильник Тонкерис, курган 3: 1 - зеркало (по: Свод памятников ..., 2010, с.415, рис.4). Курганный комплекс Таксай-1, курган 6: 2 - зуб и клык волка в золотой обкладке, южная стена ямы; 3 - зубы и клыки волка, амулеты-подвески с декора одежды женщины; 4 - ореховый короб, в котором обнаружены зубы и клыки волка, лапы двух особей волка (по: Сдыков, Лукпанова, 2013. с. 175, рис. 1; с. 179, рис. 1).

Fig.4. Tonkeris burial ground, mound 3: 1 - mirror (after: List of Monuments ..., 2010, p. 415, fig. 4). Taksai-1 mound complex, mound 6: 2 - tooth and fang of a wolf in gold lining, southern wall of the pit; 3 - teeth and fangs of a wolf, amulets-pendants from the decor of a woman's clothes; 4 - walnut box in which the teeth and fangs of a wolf, and paws of two wolf individuals were found (after: Sdykov, Lukpanova, 2013, p. 175, fig. 1; p. 179, fig. 1) 
головой они были ориентированы на запад. У изголовья воинов был обнаружен роскошный колчан, декорированный пронизями в виде протомы волка (рис. 5: 1), под колчаном был обнаружен умбон из желтого металла, костяная ложка с навершием в виде оскаленной морды волка (рис. 5: 2). На бедеренных костях выявлены мечи с бабочковидным перекрестьем, с когтевидным навершием. С правой стороны погребенных были обнаружены элементы узды выполненные в зверином стиле, у южной стенки ямы - кости лошади, возле которых находился фрагмент деревянной чаши и оковки в виде клюва хищной птицы. Во второй яме были обнаружены четыре лошади, головой ориентированне на север.

Курган 3 (диаметр - 45,0 м, высота - 1,5 м), с шатровой конструкцией из бревен, уложенных радиально, поверх которых были уложены ветки и кора. Погребальный обряд выполнен с применением огня, сооружение сгорело. В кургане на уровне древнего горизонта обнаружено коллективное захоронение. Было выявлено три погребения, головой они были ориентированы на юго-восток. Два погребения были выполнены на одной выровненной площадке и принадлежали мужчине и ребенку, судя по инвентарю девочке-подростку. Вещевой материал был представлен массивным золотым умбоном, фрагментами меча, гривной, зеркалом, бусиной, раковиной каури и лепным сосудом. Погребение 3 потревожено, кости смещены, находки представлены лепным сосудом, наконечниками стрел, наконечником гривны из кости с изображением волка, припавшего к земле (рис. 5: 3), задние и передние конечности в горизонтальном положении и находятся параллельно телу зверя. Лапы заканчиваются косыми черточками, изображающими когти. Пасть оскалена, показаны ряды жевательных зубов, Глаз миндалевидный, выпуклый, окаймлен окружностью. Ухо с выемкой. Хвост не загнут, прямой.

Таким образом, изображение волка встречается на предметах узды, ложках, в декоре колчана, вооружении в мужских погребениях и на украшениях, жертвенных столиках, зеркалах в женских погребениях. Очень важно отметить, что образ волка не встречался в рядовых захоронениях, как правило, он был зафиксирован в элитных женских погре- бениях и погребениях принадлежащих воинской верхушке, курганы, где были обнаружены предметы с изображением волка, имели подкурганную конструкцию и могильную яму с бревенчатыми выкладками.

Волк изображался частично (голова) или полностью (фигура). Фигура волка была представлена на предметах в положениях «припавший к земле», «свернувшийся в кольцо». Изображение волка усиливало значение предмета, выступая в роли оберега, амулета, наделяя любую вещь дополнительными качествами, а хозяина - сверхъестественными способностями. Лапы, зубы, клыки волка в ритуальных наборах предметов указывали, что обладатель этих наборов, человек особенный и наделен определенными качествами. Волк, будучи хищником, отличался «непреклонностью и благородством», беспощадностью, ненасытностью и являлся наиболее важным элементом шаманской вселенной (Султанова, Михайлова, 2013, с. 139). Возможно, части тела волка, обнаруженные в таксайском кургане 6 , отражают тотемистические взгляды ранних кочевников Приуралья, несмотря на то, что изображение волка отсутствовало в погребении, мы видим присутствие образа хищника во всем погребальном ритуале, совершенном при захоронении жрицы.

Значительное количество изображений волка обнаружено на конской узде, они наделяли коня новыми качествами, как это отмечено Е.С. Богдановым в случае парных изображении хищной птицы и волка, которые представляли собой амулеты, придававшие коню дополнительные способности, как смелость, сила, быстрота (Богданов, 2006, с. 46). Образ волка на украшениях, в кургане 3, Таксай-3, кургане 6, Таксай-1 представлены по разному, в одном случае в виде изображения на фрагменте гривны и в другом случае в виде зубов и клыков, подвешенных к рукаву платья, но функциональное предназначение, смысловая нагрузка в обоих случаях определяет их как обереги, защищающие человека, которому принадлежат эти украшения (Сатина, 2013, с.66; Яценко, 2006, с.83).

В традиционном сознании для образа волка характерна двойственность, выражающаяся в его взаимосвязи с силами Нижнего Мира, он является носителем разрушительного начала, был связан с тёмным, хтоническим 

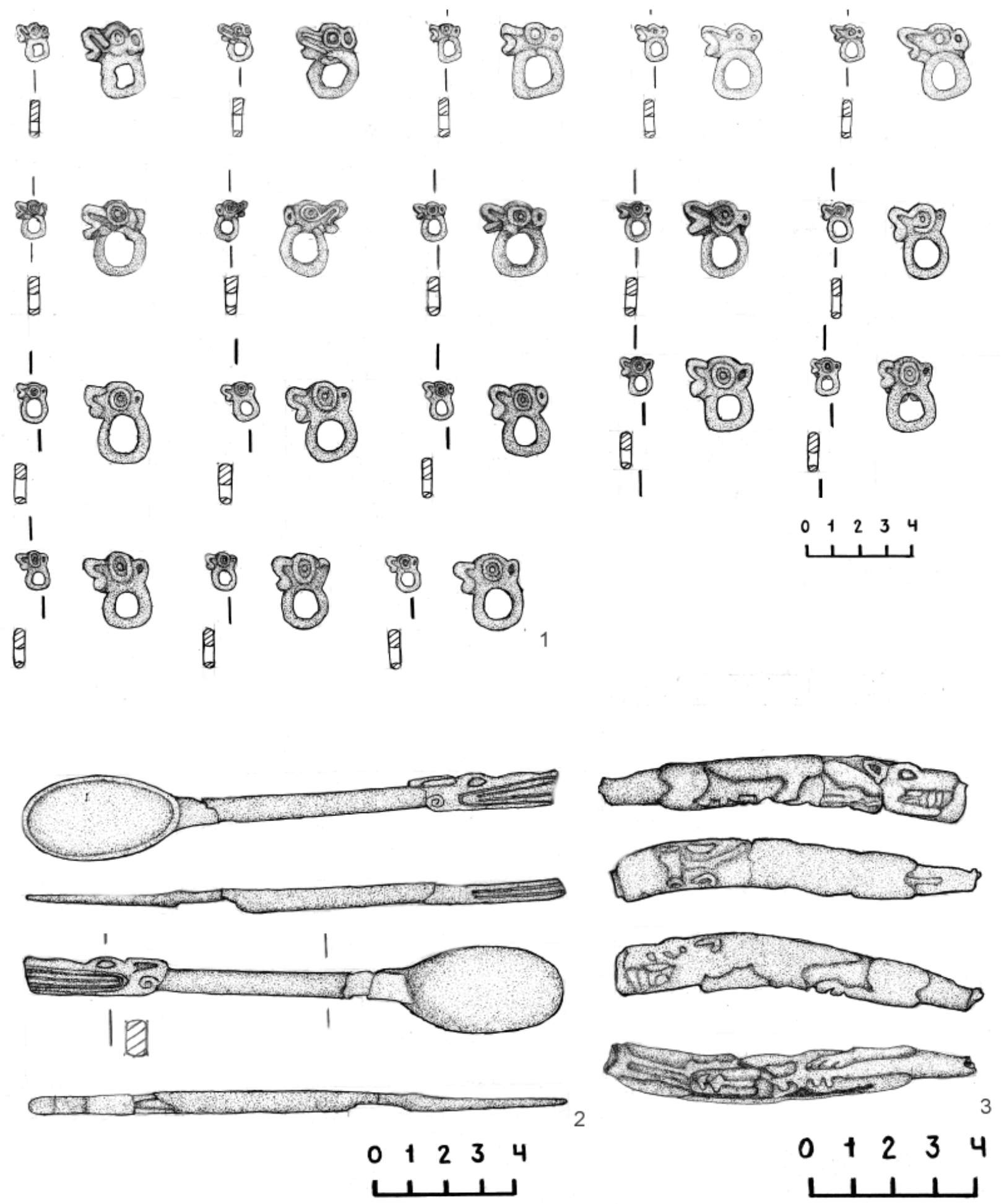

Рис.5 . Курганный комплекс Таксай-3: 1 - пронизи, курган 2; 2 - ложка, курган 2; 3 - наконечник гривны, курган 3 (раскопки автора, материал не опубликован).

Fig.5. Taksai mound complex-3: 1 - beads, mound 2;2-spoon, mound 2;3 - tip of a torc, mound 3 (excavations by the author, unpublished material).

миром будучи хищником (Липец, 1981, с.120; Кубарев, Черемисин, 1987, с. 113; Джумабекова, 1998: с. 32). С другой стороны ум, отвага, быстрота, неутомимость, гибкость связывала его с культом Богов неба, солнца и огня, которые нередко выступают и как охранители
Вселенского Закона. М.С. Самарина выделяя амбивалентность символики волка, определяет образ хищника положительным, как образ высшей свободы, не поддающийся дрессировке, бьющегося до победы, преданного до смерти, гордого, чистого, благородного 
умного и сообразительного (Самарина, 2012, с. 217). Волк являлся медиатором, обладал «мистической способностью к смене обличия и регулярному курсированию между мирами» (Бурнаков, Цыденова, 2015, с. 127). Эти его качества проецируются у кочевников Приуралья на ритуальные предметы, усиливая их семантическую нагрузку, а также на поведенческие ритуалы жрецов в кочевом обществе. Жрецы могли воплощаться в волков и обратно в человека.

В мифологии многих народов волк связан с мужскими военными союзами. С.Ю. Гуцалов выделяет психо-поведенчнские качества хищника, такие как: охотничьи повадки, сложную систему передачи информации, сравнивая их с воинами-разведчиками, внутреннюю структуру стаи с ее многоуровневыми группами, выражение эмоций (Гуцалов, 2005). А.А. Нуржанов приводит пример из египетской мифологии о боге Упуате в образе волка, который почитался как бог-покровитель, разведчик, его называли первым бойцом Осириса (Нуржанов, 2016, c. 217), герой грузинского мифа Амирани был наделен неутомимостью волка (Мелетинский, 1990 , с. 41), связаны с образом волка герои нартовских мифов, например сюжет о превращении Урызмага в пса (Иванчик, 1988, с. 41). Все неординарные и уникальные качества хищника были переняты молодыми воинами ранних кочевников, они учились у хищника боевым приемам, поведению волка, способам самовыражения. Проходя обряд инициации юноши, овладевали повадками волка, они становились людьми, «облаченными в волчью шкуру» (Гуцалов, 2005), они перерождались в волков при проведении обряда инициации и становились «воинами-псами», при этом образ волка и собаки отождествлялся. Как отмечает А.И. Иванчик, в образе волка или собаки члены военного союза становились псами-волками (Иванчик, 1988, с. 42), судя по изображениям волка на предметах узды, вооружения обнаруженных в значительном количестве на территории Приуралья, с некоторой осторожностью можно допустить, что ранние кочевники Приуралья имели прямое отношение к образу «воина-пса». Очень интересно предположение А.И. Иванчика проводящего параллель между подобными образами воинов и саками-хаумаварга, где дается один из переводов этого слова, как «волков сомы» (Иванчик, 1988, с. 42), или саков, превращавшихся в волков (Джумабекова, 1998, с. 131). Изображения волка на вооружении, узде, декоре колчана помимо функции усиления каких-либо характеристик «вещного контекста», носило геральдический характер.

Волк олицетворение сторожа Сомы-Хаомы, обожествленного галлюциногенного напитка, который упоминается в индоарийской «Ригведе» (Сома) и иранской «Авесте» (Хаома). Хаома представляет собой единство из трех воплощений: напитка, божества, растения (Мелетинский, 1990, с.567). Хаома применялась в обрядах инициации, позволяя молодым воинам пройти путь от «смерти» до перерождения. «Зоологическая головоломка» изображенная на ложечке из могильника Сынтас по мнению В.К. Федорова отражает сюжет мифа из «Ригведы» о принесении Сомы для Индры (Федоров, 1992, с. 94).

Каменные жертвенники, костяные ложки, зеркала и изображения на них оскаленного волка обнаруженные в погребениях были тесно связаны с погребальным обрядом, являясь частью ритуала «обрядового сопровождения в нижний мир». В кочевой среде складывается основная система культов, включающая в себя воинский культ, культ священного напитка, огня, предков, что по мнению А.Л. Банникова подводит нас к проблеме существования в Южном Урале особого жреческого сословия, занимающегося своеобразным обслуживанием этих культов (Банников, 2009, с. 173).

Жреческое погребение из кургана 6 могильника Таксай-1 очень ярко представляет образ волка в разных проявлениях. При анализе вещей и их расположении в могиле мы видим: 1) зубы и клыки волка как амулеты-подвески, своеобразные обереги, подвешенные к краю рукава платья, защищавшие узявимые места женщины от негативного влияния извне, 2) лапы двух особей волка сложенные в ритуальном комплексе служили вероятно для проведения определенных ритуалов, связанных с культом, 3) как было выше сказано о специфичном декоре южной стены ямы, где под полудиском, возможно олицетворяющем закат солнца выложены были зубы и клыки волка в золотой оправе что возносит образ волка до уровня культа или вместе с конем солнечного символа. 


\section{Вывод}

Образ волка получил широкое развитие в культуре населения раннего железного века (VI-IV вв. до н.э.) региона. Изображение животного является преобладающим в бестиарии древнего населения. Преимущественно этот образ встречен в элитных погребениях Казахстанского Приуралья. Все изображения волка, обнаруженные в памятниках, показывают его с оскаленной мордой, демонстрирующей бесстрашие, хищность, одновременно благородство и царственность. Образ волка придавал сверхъестественные способности, служил оберегом, являлся сакральным хтоническим существом и символом особого социального статуса.

\section{ЛИТЕРАТУРА}

Алтынбеков K. Возрожденная из пепла. Реконструкция по материалам погребения жрицы из комплекса Таксай І. Алматы: Остров Крым, 2013. 64 с.

Банников А.Л. Сакральные и социальные аспекты интерпретаций изображений на алтариках ранних кочевников Южного Урала // Сибирский сборник - 1. Погребальный обряд народов Сибири и сопредельных территорий. Кн. І. / Отв. ред. Л.Р. Павлинская. СПб.: МАЭ РАН, 2009. С. 167-175.

Богданов Е.С. Образ хищника в пластическом искусстве кочевых народов Центральной Азии (скифо-сибирская художественная традиция). Новосибирск: Изд-во ИАЭт СО РАН, 2006. 240 с.

Бурнаков В.А., Цыљенова Д.Ц. Образ волка в религиозно-мифологических представлениях хакасов (конец ХІХ - XX век) // Вестник НГУ. Серия: История, филология. 2015. Т. 14. № 3. С. 121-132.

Гуиалов С.Ю. Волчья стая. URL: http://www.darial-online.ru/2005_1/gutsalov.shtml (дата обращения: 11.08.2021)

Гуцалов С.Ю. Погребальные памятники кочевой элиты Южного Приуралья середины I тыс. до н.э. // Археология, этнография и антропология Евразии 2007. №2 (30). С. 75-92.

Гуиялов С.Ю. Погребальные сооружения могильника Кырык-Оба в Западном Казахстане. // РА. 2010. №2. C. 51-56.

Гуцалов С.Ю. Некоторые материалы из раскопок Г.А. Кушаева на территории Уральского Левобережья // УАВ. Вып. 11. Уфа: Гилем, 2011. С. 16-27.

Гуцалов С. Ю. Этнокультурная специфика могильника Кырык-Оба II // РА. 2011. № 1. С. 81-96.

Иванчик А.И. Воины-псы. Мужские союзы и скифские вторжения в Переднюю Азию // СЭ. 1988. № 5. C. 38-48.

Джумабекова Г.С. О воинских культах ранних кочевников (по материалам сюжета бронзовой курильницы) // Военное искусство кочевников Центральной Азии и Казахстана (эпоха древности и средневековья) / Отв. ред. Н.Ж. Шаханова. Алматы: Нац.Высшая школа, 1998. С. 12-28.

Засеикая И.П. Два мотива в савроматском зверином стиле - свернувшийся по кругу хищник кошачьей породы и вписанная в круг фигура козла (I - начало II в. н. э.) // Нижневолжский археологический вестник. Вып. 8. Волгоград. 2006. С. 74-110.

Кадырбаев М.К. Курганные некрополи верховьев р. Илек // Древности Евразии в скифо-сарматское время / Ред. А.И. Мелюковой, М.Г. Мошковой, В.Г. Петренко. М.: Наука, 1984. С. 84-93.

Кадырбаев М.К. Отчет Актюбинского археологического отряда за 1974 год / Архив Института археологии им. А.Х. Маргулана. Ф. 11, оп. 2, д. 1375, л.28.

Кадырбаев М.К. Захоронения воинов савроматского времени на левобережье р. Илек // Прошлое Казахстана по археологическим источникам / Отв. ред. К.А. Акишев. Алма-Ата: Наука, 1976. С. 137-156.

Королькова Е.Ф. Звериный стиль Евразии. Искусство племен Нижнего Поволжья и Южного Приуралья в скифскую эпоху VII - IV вв. до н.э.). Проблемы стиля и этнокультурной принадлежности. СПб.: Петербургское востоковедение, 2006. 272 с.

Кубарев В.Д., Черемисин Д.В. Волк в искусстве и верованиях кочевников Центральной Азии // Традиционные верования и быт народов Сибири. XIX - начало XX в. / Отв. ред. И. Н. Гемуев, А. М. Сагалаев. Новосибирск: Наука, 1987. С. 98-117.

Курманкулов Ж.К., Ишангали С., Раймкулов Б.Т. Исследования курганного отряда №2 УКАЭ в 2001г. на могильнике Кырык-оба 2 // Вопросы истории и археологии Западного Казахстана. 2002. № 1. C. 87-93.

Липеи Р.С. «Лицо волка благословлено...» (стадиальные изменения образа волка в тюрко-монгольском эпосе и генеалогических преданиях) // СЭ. 1981. № 1. С. 120-133. 
Лукпанова Я.А. Зооморфное изображение раннего железного века из некрополя Тонкерис-1 // Номады казахских степей: этносоциокультурные процессы и контакты в Евразии скифо-сакской эпохи / Отв. ред. 3. Самашев. Астана: Президентский центр культуры, 2007. С. 68-69.

Лукпанова Я.А. Знаковая функция предметов с зооморфными изображениями из кургана №6 комплекса Таксай 1 (Степное Приуралье) // Сакская культура Сарыарки в контексте исследования этносоциокультурных процессов степной Евразии / Отв. ред. А. З. Бейсенов. Алматы: HARC «БегазиТасмола», 2015. С. 154-159.

Лукпанова Я.А. Реконструкция женского костюма из элитного погребения Таксай-1: взгляд археолога // Поволжская археология. 2017. №1(19) С. 145-156.

Лукпанова Я.А. Элитарные погребения курганного комплекса Таксай // Маргулановские чтения 2018. Духовная модернизация и археологическое наследие. (19-20 апреля 2018 года) / Отв. ред. Б.А. Байтанаев. Алматы - Актобе: Институт археологии им. А.Х. Маргулана, 2018. С. 307-319.

Мифологический словарь / Ред. Е.М. Мелетинский. М.: Советская энциклопедия, 1990. 672 с.

Султанова М.Э., Михайлова Н.А. Волк в шаманской натурфилософии кочевников Центральной Азии // Вестник ЛГУ им. А. С. Пушкина. 2013. № 3. С. 135-143.

Нуржсанов А.А. О культе волка в традициях народов Евразии// Культурное наследие Евразии (с древности до наших дней) / Отв. ред. Б.А. Байтанаев. Алматы: Институт археологии им. А.Х. Маргулана, 2016. С. 216-226.

Памятники природного и историко-культурного наследия Западно-Казахстанской области.. Т 2. Сырымский район / Ред. М.Н. Сдыков. Орал, ЗКЦИ и А, 2006. 320 с.

Самарина М.С. Символика волка в культуре: от Капитолийской волчицы до волка Франциска Ассизского // Вестник ЛГУ им. А.С. Пушкина. 2012. №4. С. 216-223.

Сатина Е.К. Образ волка в декоре вещей (памятники «Звериного стиля») // Вестник КемГУ. 2013. №3 (55). С. 61-67.

Свод памятников истории и культуры Республики Казахстан. Западно-Казахстанская область. Алматы: Аруна, 2010. С.487 .

Сдыков М.Н., Гуцалов С.Ю., Бисембаев А.А. Сокровища скифов Западного Казахстана. Уральск: Полиграфсервис, 2003. 124 с.

Сдыков М.Н. Лукпанова Я.А. Ранние кочевники Западного Казахстана (на примере комплекса Таксай I). Уральск: Полиграфсервис, 2013. 292 с.

Смирнов К.Ф. Савроматы (ранняя история и культура сарматов). М.: Наука, 1964. 379 с.

Федоров В.К. Савромато-сарматские костяные ложечки: к вопросу об индоарийских корнях некоторых явлений савромато-сарматской культуры // Башкирский край. Уфа,1992. Вып. 2. С. 80-113.

Яиенко С.А. Костюм древней Евразии: ираноязычные народы. М.: Российский гос. гуманитарный ун-т; Восточная Литература, 2006. 664 с.

Kadyrbaev M.K. Denkmäler des Sauromatenadels in Westkasachstan // Das Altertum Heft. Bd. 27. 1981. p. 29-37

\section{Информация об авторе:}

Лукпанова Яна Амангелдиевна, старший научный сотрудник, Западно-Казахстанский историкокраеведческий музей (г. Уральяск, Казахстан); научный сотрудник, Институт археологии им. А.Х. Маргулана (г. Алматы, Казахстан); yanalukpanova@gmail.com

\section{REFERENCES}

Altynbekov, K. 2013. Vozrozhdennaia iz pepla. Rekonstruktsiia po materialam pogrebeniia zhritsy iz kompleksa Taksai I (Reborn from Ashes: Reconstruction by the Materials of the Priestess's Burial from Taksai I Complex). Almaty: "Ostrov Krym" Publ. (in Russian).

Bannikov, A. L. 2009. In Pavlinskaia, L. R. (ed.). Sibirskii sbornik - 1. Pogrebal'nii obryad narodov Sibiri i sopredel'nykh territorii (Siberian Collection - 1. The Burial Rite of the Peoples of Siberia and Adjacent Territories). Book I. Saint Petersburg.: Peter the Great Museum of Anthropology and Ethnography (Kunstkamera) of Russian Academy of Sciences, 167-175 (in Russian).

Bogdanov, E. S. 2006. Obraz khishchnika v plasticheskom iskusstve kochevykh narodov Tsentral'noi Azii (skifo-sibirskaia khudozhestvennaia traditsiia). (The Image of a Predator in the Plastic Arts of the Nomadic Peoples of Central Asia (the Scythian-Siberian Artistic Tradition)). Novosibirsk: Institute of Archaeology and Ethnography of the Siberian Branch, Russian Academy of Sciences Publ. (in Russian). 
Burnakov, V.A., Tsydenova, D. Ts. 2015. In Vestnik Novosibirskogo Gosudarstvennogo universiteta. Istoriia, filologiya (Bulletin of the Novosibirsk State University: History, Philology) 14 (3), 121-132 (in Russian).

Gutsalov, S. Yu. Volch'ia staia (Wolf pack). Available at: http://www.darial-online.ru/2005_1/gutsalov. $\mathrm{shtml} /$ (accessed 11.08. 2021) (in Russian).

Gutsalov, S. Yu. 2007. In Arkheologiia, etnografiia i antropologiia Evrazii (Archaeology, Ethnology \& Anthropology of Eurasia) 30 (2), 75-92 (in Russian).

Gutsalov, S. Yu. 2010. In Rossiiskaia Arkheologiia (Russian Archaeology) (2), 51-56 (in Russian).

Gutsalov, S. Yu. 2011. In Ufimskii arkheologicheskii vestnik (Ufa Archaeological Herald) 11. Ufa: "Gilem" Publ., 16-27 (in Russian).

Gutsalov, S. Yu. 2011. In Rossiiskaia Arkheologiia (Russian Archaeology) (1), 81-96 (in Russian).

Ivanchik, A. I. 1988. In Sovetskaia etnografiia (Soviet Ethnography) (5), 38-48 (in Russian).

Dzhumabekova, G. S. 1998. In Voennoe iskusstvo kochevnikov Tsentral'noi Azii i Kazakhstana (epokha drevnosti i srednevekov'ia). (Military Art of the Nomads of Central Asia and Kazakhstan (the Era of Antiquity and the Middle Ages)). Almaty: National High School, 12-28 (in Russian).

Zasetskaya, I. P. 2006. In Nizhnevolzhskii arkheologicheskii vestnik (Lower Volga Archaeological Bulletin) 9. Volgograd: Volgograd State University, 296-303 (in Russian).

Kadyrbaev, M. K. 1984. In Melyukova, A. I., Moshkova, M. G., Petrenko, V. G. (eds.). Drevnosti Evrazii $v$ skifo-sarmatskoe vremia (Antiquities of Eurasia in the Scythian-Sarmatian Period). M.: Nauka, 1984. P. 84-93(in Russian).

Kadyrbaev, M. K. Otchet Aktiubinskogo arkheologicheskogo otriada za 1974 god (Report of the Aktobe archaeological detachment for 1974). Archive of the Institute of Archaeology named after A. Kh. Margulan. Fund. 11, Inv. 2, Doisser 1375 (in Russian).

Kadyrbaev, M. K. 1976. In Akishev, K. A. (ed.). Proshloe Kazakhstana po arkheologicheskim istochnikam (The Past of Kazakhstan based on Archaeological Sources). Alma-Ata: "Nauka" Publ., 137-156 (in Russian).

Kadyrbayev, M. K. 1966. In Margulan, A. Kh., Akishev, K. A., Kadyrbayev, M. K., Orazbayev, A. M. Drevniaia kul'tura Tsentral'nogo Kazakhstana (Ancient culture of Central Kazakhstan). Alma-Ata: "Nauka" Publ., 303-433 (in Russian).

Kubarev, V. D., Cheremisin, D. V. 1987. In Gemuev, I. N., Sagalaev, A. M. (eds.). Traditsionnye verovaniia i byt narodov Sibiri. XIX-nachalo XX v. (Traditional Beliefs and Lifestyle of the Peoples of Siberia in the 19th - Early 20th XX Centuries). Novosibirsk: "Nauka" Publ., 98-117 (in Russian).

Kurmankulov, Zh. K., Ishangali, S., Raimkulov, B. T. 2002. In Voprosy istorii i arkheologii Zapadnogo Kazakhstana (Issues of History and Archaeology of Western Kazakhstan) 1. 87-93 (in Russian).

Lipets, R. S. 1981. In Sovetskaia etnografiia (Soviet Ethnography) (1), 120-133 (in Russian).

Lukpanova, Ya. A.2007. In Samashev, Z. (ed.). Nomadi kazakhskikh stepei: etnosotsiokul'turnye protsessy $i$ kontakty $v$ Evrazii skifo-sakskoi epokhi (Nomads of the Kazakh Steppes: Ethnosocial and Cultural Processes and Contacts in Eurasia of the Scythian-Saka Period). Astana: "Prezidentskii tsentr kul'tury" Publ., 68-69 (in Russian).

Lukpanova, Ya. A. 2015. In Beisenov, A. Z. (ed.) Sakskaia kul'tura Saryarki v kontekste izucheniia etnosotsiokul'turnykh protsessov stepnoi Evrazii (Saka culture of Saryarka in the context of researches of ethno-social processes of Eurasian steppe). Almaty: "Begazy-Tasmola" Publ., 154-159 (in Russian).

Lukpanova, Ya. A. 2017. In Povolzhskaya arkheologiya (Volga River Region Archaeology) 19 (1), 145-156 (in Russian).

Lukpanova, Ya. A. 2018. In Baitanayev, B.A. (ed.). Margulanovskie chteniya-2018. Dukhovnaya modernizatsiya i arkheologicheskoe nasledie (19-20 aprelya 2018 goda) (Margulan Readings - 2018. Spiritual Modernization and Archaeological Heritage (April 19-20, 2018)). Almaty-Aktobe: ZHK "S. T. Zhanədílov Tipografy" Publ., 307-319 (in Russian).

Meletinskii, E. M. (ed.). 1990. Mifologicheskii slovar' (Mythological Dictionary). Moscow: "Sovetskaia entsiklopediia" Publ. (in Russian).

Nurzhanov, A. A. 2016. In Baitanayev, B. A. (ed.). Kul'turnoe nasledie Evrazii (s drevnosti do nashikh dney) (Cultural Heritage of Eurasia (from Antiquity to Present Day)). Almaty: A. Kh. Margulan Institute of Archaeology, 216-226 (in Russian).

Sdykov, M.N.(ed.). 2006. Pamyatnikiprirodnogo i istoriko-kul'turnogonaslediya Zapadno-Kazakhstanskoy oblasti 2. Syrymsky raion (Monuments of Natural and Historical Cultural Heritage of the West Kazakhstan Region. 2. Syrymsky District. Oral: "ZKTCI and A” Publ. (in Russian). 
Samarina, M. S.2012. In Vestnik Leningradskogo Gosuderstvennogo Universiteta (Bulletin of the Leningrad State University) (4), 216-223 (in Russian).

Satina, E. K. 2013. In Vestnik KemGU (Bulletin of Kemerovo State University) 55 (3), 61-67 (in Russian). 2010. Svod pamyatnikov istorii i kultury Respubliki Kazakhstan. Zapadno-Kazakhstanskaia oblast' (Corpus of Sites of Historical and Cultural of the Republic of Kazakhstan. West Kazakhstan Region). Almaty: "Mamatay Agency" Publ. (in Russian).

Sdykov, M. N., Gutsalov, S. Yu., Bisembaev, A. A. 2003. Sokrovishcha skifov Zapadnogo Kazakhstana (Treasures of the Scythians of West Kazakhstan). Uralsk: "Poligrafservis" Publ. (in Russian).

Sdykov, M. N. Lukpanova, Ya. A. 2013. Rannie kochevniki Zapadnogo Kazakhstana (na primere kompleksa Taksai I) (Early Nomads of the Western Kazakhstan (example of Taksai I Complex)). Uralsk: "Poligrafservis" Publ. (in Russian).

Smirnov, K. F. 1964. Savromaty. Ranniaia istoriia i kul'tura sarmatov (The Sauromatians. Early History and Culture of the Sarmatians). Moscow: "Nauka" Publ. (in Russian).

Sultanova M. E., Mikhailova N. A. 2013.In Vestnik LGU im. A. S. Pushkina (Bulletin LSU named after A.S. Pushkin) 3, 135-143 (in Russian).

Fedorov, V. K. 1992. In Bashkirskii krai (Bashkortostan) 2, Ufa, 80-113 (in Russian).

Yatsenko, S. A. 2006. Kostium Drevnei Evrazii (iranoiazychnye narody) (Costume in Early Eurasia (Iranian-Speaking Peoples)). Moscow: Russian State University for the Humanities; "Vostochnaia Literatura" Publ. (in Russian).

Kadyrbaev, M. K. 1981. In Das Altertum Heft. Bd. 27, 29-37 (In German).

\section{About the Author:}

Lukpanova Yana A. History and Archaeology Center of Western Kazakhstan. Dostyk St., 184, Uralsk, 090000, Kazakhstan; A. Kh. Margulan Institute of Archaeology, Ministry of Education and Science of the Republic of Kazakhstan. Dostyk Ave., 44, Shevchenko St., 28, Almaty, 050010, Republic of Kazakhstan. yanalukpanova@ gmail.com 